\title{
УТОЧНЕНИЕ КОМПЕТЕНЦИИ СУДА АПЕЛЛЯЦИОННОЙ ИНСТАНЦИИ
}

\section{CLARIFICATION OF THE COMPETENCE OF THE COURT OF APPEAL}

\section{K. Vezdenev}

Summary. The article is devoted to the problem of partial coincidence of issues resolved by the appellate instance and courts considering materials in accordance with Article 397 of the Code of Criminal Procedure of the Russian Federation. The requirements established by the criminal procedure law for the powers of the courts of these instances are analyzed. Objective and subjective circumstances are considered, in which it is more expedient to distinguish between related issues of appeal, so that the arguments of complaints and submissions to instances that differ in their functional purpose do not duplicate each other. The comparison of the procedure and organization of the work of courts of various levels is carried out, the reasons and conditions for the possibility of changing the procedure for appealing certain categories of arguments of the parties are identified. The competence of the court of appeal is analyzed and clarification of the powers of the courts of second instance is proposed. Arguments are given about the need to amend the criminal procedure legislation, establishing a different procedure for resolving emerging issues after the announcement of the verdict.

Keywords: verdict, appeal, argument of the appeal, justification, specific circumstances of the criminal case, appellate court.

\author{
Везденев Константин Евгеньевич \\ Федеральный судья, Центральный районный суд \\ 2. Тюмени; аспирант, Тюменский государственный \\ университет \\ safarkada1981@yandex.ru
}

Аннотация. Статья посвящена проблеме частичного совпадения вопроСOB, разрешаемых апелляционной инстанцией и судами, рассматривающими материалы в порядке ст. 397 УПК РФ. Анализируются установленные уголовно-процессуальным законом требования к полномочиям судов указанных инстанций. Рассматриваются объективные и субъективные обстоятельства, при которых целесообразнее разграничить смежные вопросы обжалования, с тем, чтобы доводы жалоб и представлений в различные по своему функциональному назначению инстанции не дублировали друг друга. Проводится сопоставление порядка и организации работы судов различного уровня, выявляются причины и условия возможности изменения процедуры проверки обоснованности отдельных категорий доводов сторон. Подвергается анализу компетенция суда апелляционной инстанции и предлагается уточнение полномочий судов второй инстанции. Приводятся доводы о необходимости внесения изменений в уголовно-процессуальное законодательство, устанавливающие разный порядок разрешения возникающих вопросов после оглашения приговора.

Ключевые слова: приговор, обжалование, довод жалобы, обоснование, обстоятельство уголовного дела, апелляционная инстанция.

но остается «в тени», на что обоснованно было указано Николюк В.В.[1].

Следовательно, при наличии в судебных решениях, указанных выше оснований для обжалования, стороны, на сегодняшний день, вправе самостоятельно выбирать в каком именно порядке и в какой суд они могут обратиться с соответствующей жалобой - в апелляционном в вышестоящую судебную инстанцию или в порядке исполнения приговора в суд того же уровня.

Так, в случае поступления апелляционной жалобы или представления со ссылкой на то, что суд первой инстанции ошибочно не принял решение о распоряжении каким-либо вещественным доказательством, уголовное дело будет направлено в апелляционную инстанцию для принятия решения об обоснованности заявленных доводов.

Следует заметить, что процедура апелляционного судопроизводства займет в этом случае гораздо боль- 
ший срок, чем рассмотрение жалобы с аналогичными доводами, но внесенной в соответствии с положениями ст. 396 УПК РФ в порядке исполнения приговора.

Если после поступления апелляционной жалобы суд первой инстанции обязан разослать всем сторонам ее копии с обязательным предоставлением разумного срока для внесения возражений (как правило, 10-14 дней), затем, при отсутствии других жалоб или дополнений к ранее поданной, уголовное дело направляется в суд апелляционной инстанции, который в течение 30 дней рассматривает уголовное дело и принимает решение по доводам сторон, после чего возвращает уголовное дело в суд первой инстанции.

Таким образом, ориентировочный срок, который проходит между поступлением апелляционной жалобы и возвращением уголовного дела из суда апелляционной инстанции в большинстве случаев составляет примерно 2 месяца.

При рассмотрении тех же доводов, но в порядке исполнения приговора суд первой инстанции назначает дату судебного заседания, о чем извещает стороны не позднее, чем за 14 дней до его проведения.

С учетом времени, которое займет выдача сторонам копий судебного решения, общий срок для разрешения указанных выше вопросов не составит более 1 месяца, что, по мнению Л.А. Шабалиной, способствует соблюдению разумных сроков[2].

К этому следует добавить, что апелляционная инстанция призвана проверять законность судебных решений на предмет наличия существенных нарушений закона, наличие которых влечет их отмену либо изменение с улучшением или ухудшением положения осужденного.

Не является оправданным и целесообразным загружать апелляционную инстанцию проверкой доводов сторон, возможное удовлетворение которых не окажет никакого влияния на улучшение или ухудшение положения осужденного.

К примеру, маловероятно, что для осужденного или его защитника имеет принципиальное значение, вернут ли потерпевшему какое-либо доказательство или его уничтожат по вступлении приговора в законную силу, так как на назначенное ему ранее судом первой инстанции наказание этот факт никакого воздействия не окажет.

Даже если подсудимый посчитает, что вопрос, разрешаемый в порядке исполнения приговора важен для него, как, например, при зачете срока отбывания наказания, он имеет право лично принять участие в судебном заседании, где будут рассматриваться данные вопросы, изложить и обосновать суду свою позицию и впоследствии, в случае своего несогласия, обжаловать в апелляционном порядке принятое решение суда первой инстанции.

В любом случае подсудимого никто не лишает права на принятие личного участия в судебном заседании, получение копии судебного решения и последующее обращение в апелляционную инстанцию с жалобой на состоявшееся решение, то есть, как подчеркивал П.В. Тепляшин, будет гарантирована судебная защита[3].

Аналогичные процессуальные права и гарантии распространяются на всех остальных возможных участников уголовного процесса, поэтому нет оснований полагать, что исключение из компетенции суда апелляционной инстанции рассмотрения жалоб и представлений сторон на не вступившие в законную силу решения судов первой инстанции в части обжалования перечня вопросов, указанного в ст. 397 УПК РФ, приведет к нарушению права сторон на обжалование судебных решений, нарушению принципа справедливости, что, согласно замечанию С.В. Чубракова, недопустимо в уголовном процессе[4].

Предлагаемое изменение порядка апелляционного обжалования позволит более оперативно рассматривать жалобы и представления сторон, касающиеся вопросов, указанных в ст. 397 УПК РФ, а также приведет к снижению нагрузки судов апелляционной инстанции.

Не случайно законодатель выделил в отдельную главу УПК РФ широкий круг вопросов, возникающий в процессе исполнения приговора, когда порой становятся явными и очевидными некоторые нарушения закона и ошибки, имеющиеся в судебных решениях, но оставшиеся не обжалованными сторонами и не исправленными судами апелляционной инстанции.

Указанный выше перечень вопросов настолько обширен, что одно из оснований звучит, как «устранение сомнений и неясностей, возникающих при исполнении приговора», то есть носит всеобъемлющий и универсальный характер, к которому можно отнести практически любой фрагмент приговора.

Суд, рассмотревший уголовное дело по существу или находящийся по месту отбывания осужденным наказания, вправе устранить допущенную им неясность в приговоре, то есть, тем самым, фактически выполнив функцию апелляционной инстанции по ограниченному требованиями уголовно-процессуального закона кру- 
гу вопросов, не касаясь существа принятого им ранее итогового решения по уголовному делу.

Следовательно, в настоящее время, согласно действующему уголовно-процессуальному законодательству, исправление нарушений закона в судебных решениях не является исключительной прерогативой вышестоящих судебных инстанций, в том числе, апелляционной, так как ст. 396 УПК РФ предоставляет право в ограниченном объеме корректировать и уточнять судебные решения первой инстанции судебным органам того же уровня.

Соответственно, если уже сейчас суды апелляционной инстанции не имеют абсолютных полномочий по установлению и устранению нарушений закона в судебных решениях первой инстанции, настало время для разграничения компетенции судов двух различных инстанций в части перечня вопросов, которые правомочны рассматривать каждая из них после вынесения итогового судебного решения по существу предъявленного обвинения.

Кроме того, нельзя согласиться с одновременным существованием в УПК РФ двух разных способов обжалования одних и тех же нарушений закона.

При неправильном зачете срока отбывания наказания осужденный вправе сразу же после провозглашения приговора обратиться в вышестоящий суд с апелляционной жалобой по данному основанию, но может и подождать вступления приговора в законную силу и разрешить данный вопрос в порядке исполнения приговора.

Оба приведенных выше способа обжалования одного и того же судебного решения по одним и тем же основаниям установлены разными главами УПК РФ, имеют альтернативный характер применения и при отсутствии приоритета относительно друг друга дают возможность автору жалобы самостоятельно выбирать между ними или использовать оба, в случае отказа апелляционной инстанции в удовлетворении соответствующих доводов жалобы.

При этом нарушается установленная уголовно-процессуальным законом последовательность обжалования судебных решений, поскольку решения суда апелляционной инстанции могут быть изменены или отменены только вышестоящими судебными инстанциями, а именно - кассационной и надзорной.

Мы полагаем, что механизм обжалования судебных решений не может носить альтернативный характер, предусматривающий возможность одновременного существования различных порядков обжалования, которые установлены разными главами и статьями УПК РФ, но могут применяться на одной и той же стадии уголовного процесса.

Стороны при обжаловании судебных решений в апелляционном порядке не должны иметь других установленных уголовно-процессуальным законом возможностей для удовлетворения своих доводов, кроме последующего возможного обращения в кассационную и надзорную инстанции.

Трудно не согласиться с мнением Ю.К. Якимовича [5], согласно которого механизм обжалования судебных решений должен представлять собой целостную, взаимосвязанную, функционально структурированную систему, построенную на единых организационно-правовых принципах, с тем, чтобы любые доводы сторон и основания для обжалования судебных решений были проверены и получили свою объективную оценку в разумные (минимально возможные) сроки тем судом, к компетенции которого относится их разрешение.

Каждый участник судебного разбирательства должен знать, к компетенции какого именно суда относится разрешение поставленных им в своих жалобах или представлении вопросов, каков порядок их рассмотрения и принятия итогового решения.

По этой причине перед подсудимым не должен стоять вопрос - сразу внести апелляционную жалобу в вышестоящую судебную инстанцию на только что провозглашенный приговор суда в части неправильного исчисления срока отбывания назначенного ему наказания или дождаться вступления судебного решения в законную силу, после чего обратиться в суд первой инстанции в порядке решения вопросов, связанных с исполнением приговора.

Уголовно-процессуальный закон должен четко и единообразно разграничить компетенцию суда каждой инстанции, отнеся к предмету их ведения строго определенный их уровнем перечень вопросов, подлежащих рассмотрению и разрешению.

Недопустимо наличие в уголовно-процессуальном законе совпадающих или пересекающихся между собой вопросов, которые в зависимости от субъективных обстоятельств (волеизъявления сторон), могут относиться к компетенции судебных органов разного уровня, что является проблемой, на которой акцентировала свое внимание Л.А. Пупышева[6].

Именно закон, а не стороны, должен определять порядок обжалования судебных решений, не предус- 
матривая при этом каких-либо дополнительных вариантов и побочных решений.

Требует уточнения и компетенция судебной инстанции каждого уровня при обжаловании сторонами решений суда первой инстанции.

Предлагаем возможным исключение из компетенции суда апелляционной инстанции решение вопросов, предусмотренных ст. 397 УПК РФ, так как данные обстоятельства должны быть разрешены или в приговоре суда первой инстанции, либо судом этого же уровня, но в порядке исполнения приговора.

Апелляционная инстанция не должна брать на себя разрешение вопросов, отнесенных уголовно-процессуальным законом к компетенции нижестоящих судов.

Только в случае поступления от участвующих в деле сторон апелляционных жалоб и представлений на решения судов, вынесенные при рассмотрении вопросов в порядке ст. 397 УПК РФ, апелляционная инстанция вправе проверить правильность выводов судов первой инстанции, но не решать самостоятельно вопросы, для которых уголовно-процессуальный закон установил другой порядок рассмотрения.

Предметом апелляционного рассмотрения должны быть в первую очередь ключевые вопросы, разрешаемые судом первой инстанции при постановлении приговора, а именно - доказанность вины подсудимого, правильность квалификации его действий, справедливость назначенного наказания.

К предмету апелляционного рассмотрения также можно отнести ряд других вопросов - гражданский иск, процессуальные издержки, вещественные доказательства, если в приговоре суда они получили неправильное разрешение.

Например, если в резолютивной части приговора суд ошибочно указал на необходимость уничтожения вещественного доказательства вместо его возвращения потерпевшему или подсудимому, неправильно разрешил гражданский иск, взыскав большую или меньшую сумму, чем было необходимо, либо оставил гражданский иск без рассмотрения при отсутствии на то, указанных в законе оснований, именно апелляционный суд должен установить факт нарушения закона судом первой инстанции и внести необходимые изменения в не вступившее в законную силу судебное решение.

Другими словами, суд первой инстанции, рассмотрев уголовное дело по существу, высказав в приго- воре свое мнение по указанным в УПК РФ вопросам, не может самостоятельно корректировать свое собственное решение в той части, где уже имеется суждение суда, независимо от того, правильное оно или нет.

Если суд первой инстанции ошибочно указал, что какое-либо вещественное доказательство надлежит вернуть определенному им лицу или необходимо снять арест с арестованного имущества, то он лишен возможности в последующем указать иное, так как решения суда одного и того же уровня не могут противоречить друг другу.

В этом случае только вышестоящая судебная инстанция, как правило, апелляционная, вправе внести необходимые изменения в состоявшееся судебное решение при поступлении на ее рассмотрение соответствующих доводов.

С другой стороны, если суд первой инстанции по каким-то причинам ошибочно оставил в приговоре вопрос о судьбе отдельно взятого вещественного доказательства не разрешенным, либо, правильно установив в описательно-мотивировочной части приговора размер имущественного вреда, подлежащего взысканию с виновного в рамках рассмотренного гражданского иска, допустил опечатку в резолютивной части, то есть в случаях, когда мнение суда первой инстанции либо не было выражено, либо в силу допущенной технической ошибки могло получить двойное толкование целесообразнее не направлять уголовное дело на рассмотрение суда апелляционной инстанции, а для более быстрого и оперативного разрешения вопросов, не вызывающих у сторон споров или различных толкований, применить другой порядок, успешно и эффективно используемый в других отраслях права.

Ранее мы уже анализировали проблему отсутствия у суда первой инстанции в уголовном судопроизводстве (в отличие от КоАП РФ) установленной уголовно-процессуальным законом возможности для исправления описок и опечаток в судебных решениях, не касающихся существа принятого решения.

При имплементации данной нормы в уголовно-процессуальное законодательство из административного суды первой инстанции получили бы юридическую возможность более оперативно и своевременно разрешать целый ряд вопросов, возникающих после оглашения судебных решений и выдаче сторонам их копий.

Не следует расценивать предоставление судам первой инстанции полномочий по частичной проверке своих же решений, как ограничение компетенции апелляционной инстанции. 
Как уже было ранее сказано, у сторон сохраняется возможность обратиться с апелляционной жалобой и представлением в вышестоящий суд в случае наличия, по их мнению, нарушений закона в любых решениях суда первой инстанции, в том числе уточняющего или разъясняющего характера, то есть данный круг вопрос не выходит из компетенции судов апелляционной инстанции, так как стороны вправе перенести в нее разрешение указанных вопросов, при несогласии с содержанием решений судов первой инстанции, что обеспечит контроль за законностью судебных решений, как указывал Б.Т. Безлепкин[7].

Аналогичное мнение было высказано А.А. Барыгиной[8]. При этом, Д.В. Тулянский полагал, что в данной стадии уголовного процесса суд правосудие не осуществляет[9]. Наиболее взвешенным и справедливым представляется позиция А.С. Червоткина, считающего, что действия суда на любой стадии должны находиться в правовом поле и способствовать защите нарушенных прав граждан[10].

Главной целью внесения в УПК РФ предлагаемых нами изменений является уточнение компетенции двух судебных инстанций, с тем, чтобы второстепенные вопросы, не относящиеся к существу принятого судом первой инстанции решения, могли быть разрешены этим же судом с обязательным сохранением за апелляционной инстанцией права проверить законность принимаемых решений в случае поступления жалоб и представлений от участников судебного разбирательства.

Апелляционная инстанция, в свою очередь, будет заниматься проверкой не вступивших в законную силу судебных решений на предмет наличия оснований для их отмены или изменения с последующим улучшением или ухудшением положения осужденного, то есть решением ключевых вопросов по уголовному делу.

\section{ЛИТЕРАТУРА}

1. Николюк В.В. Судебный контроль за исполнением приговора // Вестник ОГУ № 3 март 2006. С. 130.

2. Тепляшин П.В. Перспективы расширения судебно-правового регулирования уголовно-исполнительных отношений // Российская юстиция. 2010. № 4. C. 60.

3. Чубраков С.В. Проблема принципов в уголовно-исполнительном праве: история и современность / под ред. В.А. Уткина. - Томск: Издательский дом ТГУ, 2015. С. 52.

4. Якимович Ю.К. 0 некоторых вопросах дальнейшей дифференциации уголовного процесса России // Уголовная юстиция. — 2013. — № 1 (1).— С. 5964.

5. Пупышева, Л.А. Уголовно-процессуальная деятельность в стадии исполнения приговора: проблемы правоприменительной практики // Уголовно-исполнительная система сегодня: взаимодействие науки и практики: материалы науч.-практ. конф., 9-10 нояб. 2016 г. / отв. ред. А.Г. Антонов. Новокузнецк: ФКОУ ВО Кузбасский институт ФСИН России, 2016. С. 147-149.

6. Шабалина Л.А. Обеспечение прав, свобод и законных интересов, осужденных при рассмотрении и разрешении вопросов, связанных с исполнением приговора: дис. ... канд. юрид. наук.- Владимир, 2012.

7. Уголовный процесс России: учебное пособие. / Б.Т. Безлепкин. — 6-е изд. перераб. и доп. М. 2010. С. 412.

8. Барыгина, А.А. Процессуальные проблемы применения института условно-досрочного освобождения от отбывания наказания // Российская юстиция 2014. № 2.

9. Тулянский, Д.В. Осуществляет ли суд правосудие в стадии исполнения приговора? // Журнал российского права. № 7. 2001.

10. Червоткин А.С. Процессуальные особенности рассмотрения вопросов, возникающих на стадии исполнения приговора // Российская юстиция. 2015. № 10. 